
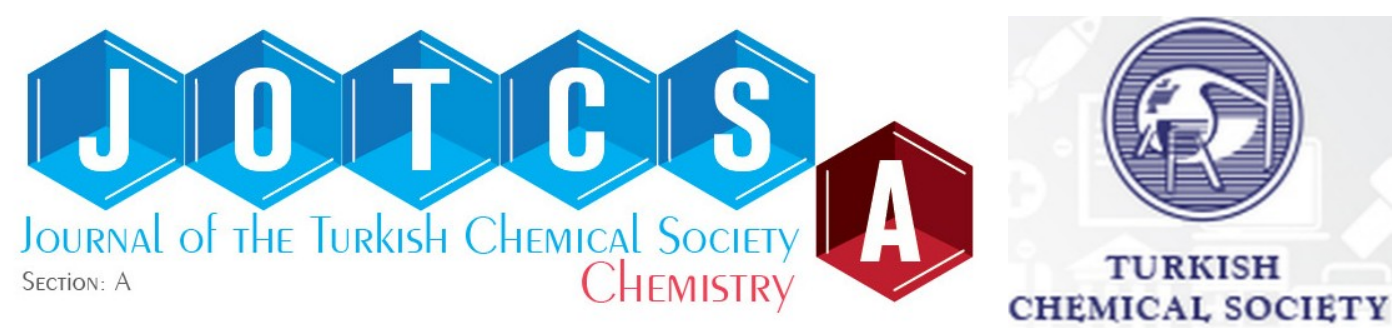

\title{
Cefoperazone metal complexes and their antimicrobial investigations
}

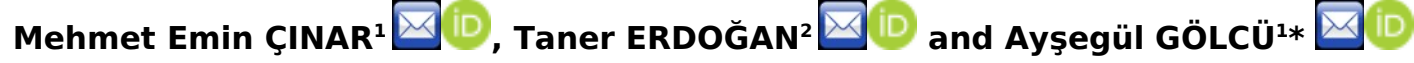 \\ ${ }^{1}$ Istanbul Technical University, Faculty of Science and Letters, Department of Chemistry, Istanbul, Turkey \\ ${ }^{2}$ Kocaeli Univ, Kocaeli Vocational School, Dept Chem \& Chem Proc Technol, Kocaeli, Turkey.
}

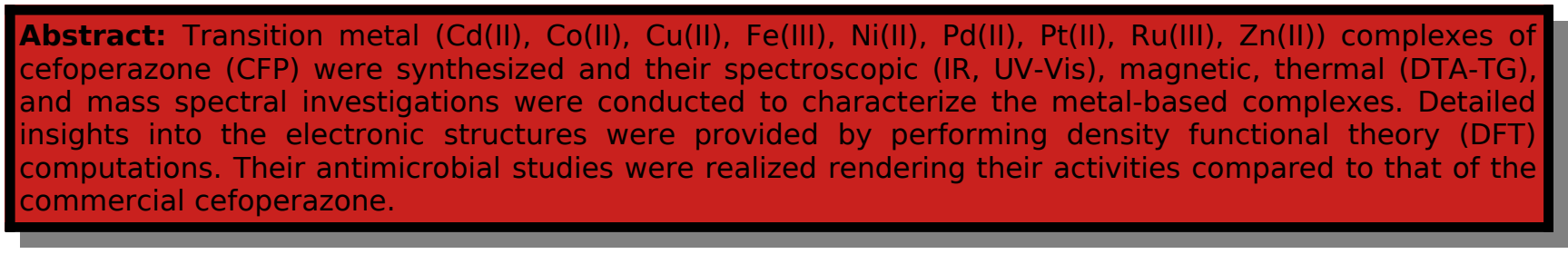

Keywords: Cefoperazone, metal complexes, antimicrobial studies, computation.

Submitted: April 16, 2020. Accepted: January 14, 2021.

Cite this: Çınar M, Erdoğan T, Gölcü A. Cefoperazone metal complexes and their antimicrobial investigations. JOTCSA. 2021;8(1):375-90.

DOI: https://10.18596/jotcsa.721414.

*Corresponding author. E-mail: aysgolcu@itu.edu.tr.

\section{INTRODUCTION}

Cephalosporins are in the group of ß-lactams and have been utilized since 1948 widely $(1,2)$. All the cephalosporins were derived from 7-amino cephalosporinic acid. Incorporation of side chains altered both the anti-bacterial activity and the pharmacokinetic properties. They are categorized into five classes based on their antimicrobial activities. The new classes demonstrate greater activity against Gram-negative bacteria with respect to the earlier classes. Cephalosporins impede the synthesis of bacterial cell-wall. However, the presence of ß-lactamases can destruct the $ß$-lactam ring and hence deactivate cephalosporins (3). Cefoperazone is placed in a third class of cephalosporin antibiotics, including cefixime (CFX) and cefpodoxime (CPD) and more resistant to hydrolysis by the $\beta$-lactamases, with higher efficiency against gram negative and lower efficacy against gram positive. They also play important roles in treatment of infections, such as Pseudomonas bacterial, respiratory and urinary contagions. Cephalosporins form metal-based complexes via coordination of metal ions to electron donor units of Cephalosporins, which significantly affects chemical properties of antibiotics and hence their antimicrobial activities, toxicities, pharmacokinetics and resistance to hydrolysis (4). Some important works have been devoted to the synthesis and characterization of metal complexes (Fe(III), $\mathrm{Co}(\mathrm{II}), \mathrm{Ni}(\mathrm{II}), \mathrm{Cu}(\mathrm{II}), \mathrm{Cd}$ (II), $\mathrm{Cr}(\mathrm{III}), \mathrm{Mn}(\mathrm{II}), \mathrm{Zn}(\mathrm{II})$ and $\mathrm{Hg}(\mathrm{II})$ ) of cefoperazone $(3,5)$. Complexation behavior of cefoperazone was described in the literature to be both bidentate and tetradentate proposed in metal coordinated dimer complexes and in polymeric structure with the cefoperazone ligand bridging between metal centers (Figure 1). We report here the synthesis, characterization and antimicrobial investigations of cefoperazone metal complexes. To the best of our knowledge, there is no DFT level studies employed to elaborate experimental findings. In this work, computation was utilized to shed light on the intriguing properties of cefoperazone metal complexes. 


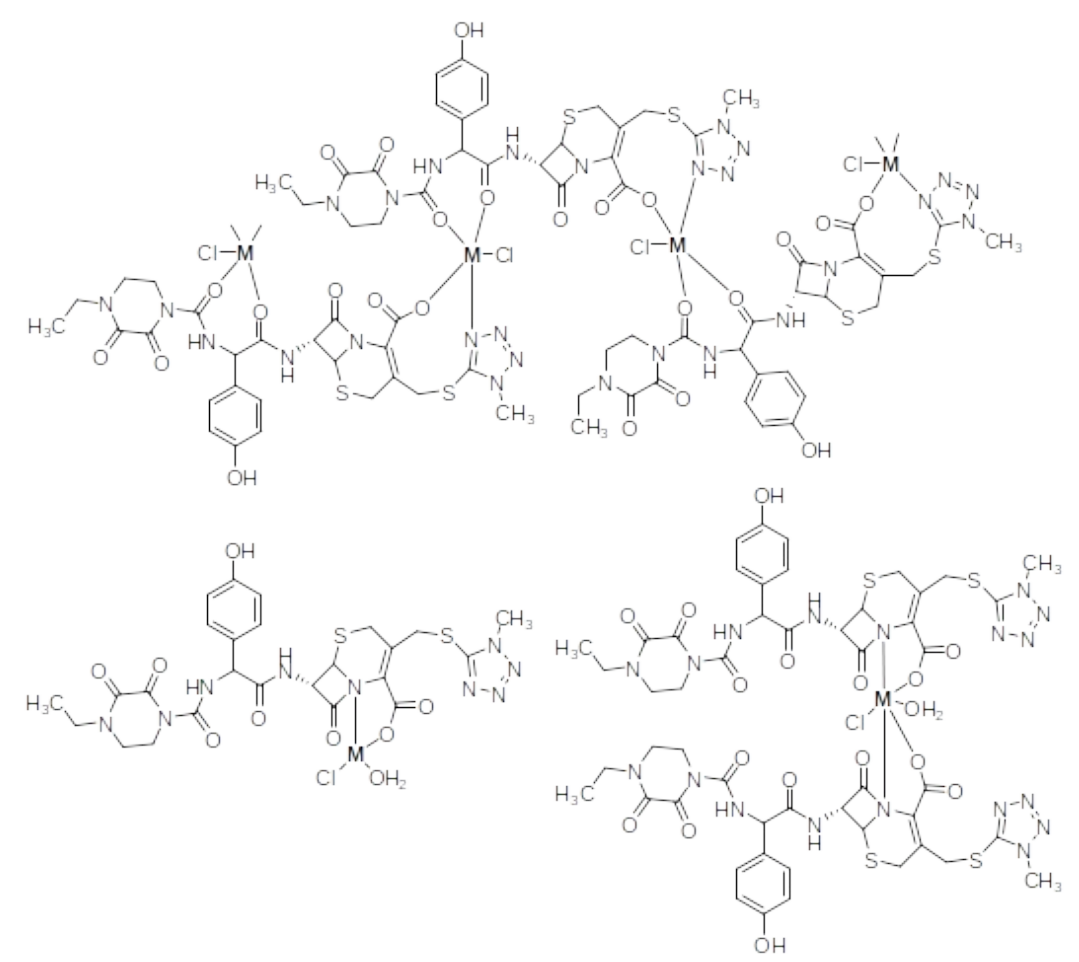

Figure 1. Reported cefoperazone metal complexes (3-5).

\section{EXPERIMENTAL SECTION}

\section{Chemicals and apparatus}

Cefoperazone sodium (CFP) and was supplied from Pfizer Pharm. Inc. (Istanbul, Turkey). EtOH, nhexane, $\mathrm{ACN}, \mathrm{DEE}, \mathrm{MeOH}$, acetone, $\mathrm{CuCl}_{2} \cdot 2 \mathrm{H}_{2} \mathrm{O}$, $\mathrm{CoCl}_{2} \cdot 6 \mathrm{H}_{2} \mathrm{O}, \quad \mathrm{NiCl}_{2} \cdot 6 \mathrm{H}_{2} \mathrm{O}, \quad \mathrm{ZnCl}_{2} \cdot 2 \mathrm{H}_{2} \mathrm{O}, \quad \mathrm{CdCl}_{2}$, $\mathrm{FeCl}_{3} \cdot 6 \mathrm{H}_{2} \mathrm{O}, \mathrm{PtCl}_{2}$ and $\mathrm{RuCl}_{3} \cdot 3 \mathrm{H}_{2} \mathrm{O}, \mathrm{NaOH}$, anhydrous $\mathrm{Na}_{2} \mathrm{SO}_{4}, \mathrm{H}_{2} \mathrm{SO}_{4}$ and $\mathrm{HCl}$ were purchased from Fluka (Darmstadt, Germany) and Merck (Darmstadt, Germany). All the chemicals and solvents were reagent grade and were used as purchased. All samples were prepared in spectrophotometric grade solvents.

Aluminum Thin layer chromatography (TLC) plates, silica gel coated with fluorescent indicator F254, were obtained from Merck (Darmstadt, Germany). Elemental analyses were performed using a LECO CHNS 932 elemental analyzer (TUBITAK instrumental analysis laboratory, Ankara, Turkey). Infrared spectra of the compounds were obtained using $\mathrm{KBr}$ pellets $\left(4000-400 \mathrm{~cm}^{-1}\right)$ with a Shimadzu FTIR 8300 spectrometer. The UV-Vis spectra were obtained in the 200-1000 $\mathrm{nm}$ range by a PerkinElmer Lambda 45 spectrophotometer (Kahramanmaras Sutcu Imam University, Chemistry Department, Kahramanmaras, Turkey). Mass analyses of the metal-based compounds were performed under atmospheric pressure using chemical ionization method on an LC/MS-APCI Agilent 1100 MSD spectrometer (TUBITAK instrumental analysis laboratory, Ankara, Turkey and Central Research Laboratory of the Inonu University, Malatya, Turkey). ${ }^{1} \mathrm{H}$ NMR and ${ }^{13} \mathrm{C} N M R$ spectra were recorded on a Bruker Avence DPX400 instrument. TMS was used as an internal standard and DMSO- $\mathrm{d}_{6}$ as a solvent (TUBITAK instrumental analysis laboratory, Ankara, Turkey). The quantity of metal in the metal complexes was measured using Ati Unicam 929 Model AA Spectrometer, operating the parameters; Nebulizer flow: $0.8 \mathrm{~L} / \mathrm{min}$, auxiliary flow: $0.2 \mathrm{~L} / \mathrm{min}$, plasma flow: $1.7 \mathrm{~L} / \mathrm{min}$, Sample flow rate: $1.5 \mathrm{~mL} / \mathrm{min}$, equilibration time: $15 \mathrm{~s}$, RF power: $1452 \mathrm{~W}$ (Kahramanmaras Sutcu Imam University, USKIM, Kahramanmaras, Turkey). Thermal analysis and stability of the metal complexes were realized under a nitrogen atmosphere at a heating rate 10 ${ }^{\circ} \mathrm{C} / \mathrm{min}$ on a Pyris Diamond DTA/TG DSC Thermal System (Çanakkale 18 Mart University, University, Faculty of Arts and Sciences, Department of Chemistry, Çanakkale, Turkey). Magnetic susceptibility measurements were performed by applying the Gouy method involving $\mathrm{Hg}\left[\mathrm{Co}(\mathrm{SCN})_{4}\right]$ as a standard. Conductivity measurements were conducted on Toa Conductivity Meter 405 (DSi, Kahramanmaras, Turkey). Melting points of the compounds were measured on Electrothermal 9200 and uncorrected. Molecular structures were drawn using ChemDraw software.

\section{Synthesis}

General procedure

For $\mathrm{Cu}(\mathrm{II}), \mathrm{Co}(\mathrm{II}), \mathrm{Ni}(\mathrm{II}), \mathrm{Zn}(\mathrm{II}), \mathrm{Cd}(\mathrm{II}), \mathrm{Fe}(\mathrm{III})$ and $\mathrm{Ru}$ (III) complexes: To a solution of $5.00 \mathrm{~mL}$ of deionized water and $20.0 \mathrm{~mL}$ of methanol in 100 
$\mathrm{mL}$ two-necked round-bottomed flask was added CEFOBID (668 $\mathrm{mg}, 1 \mathrm{mmol})$. The solute was dissolved by heating the mixture up to reflux temperature on a magnetic stirrer. To the prepared solution was introduced $1 \mathrm{mmol}$ of metal salt $\left(\mathrm{CuCl}_{2} \cdot 2 \mathrm{H}_{2} \mathrm{O}, \mathrm{CoCl}_{2} \cdot 6 \mathrm{H}_{2} \mathrm{O}, \mathrm{NiCl}_{2} \cdot 6 \mathrm{H}_{2} \mathrm{O}, \quad \mathrm{ZnCl} \cdot 2 \mathrm{H}_{2} \mathrm{O}\right.$, $\mathrm{CdCl}_{2}, \mathrm{FeCl}_{3} \cdot 6 \mathrm{H}_{2} \mathrm{O}$ and $\mathrm{RuCl}_{3} \cdot 3 \mathrm{H}_{2} \mathrm{O}$ ) in $10 \mathrm{~mL}$ of methanol. Resulting mixture was refluxed for $24 \mathrm{~h}$ and the completion of reaction was checked by TLC. After that the mixture was filtered off and the solid residue was successively washed with deionized water, $\mathrm{MeOH}$, and diethyl ether. The solid products were dried under vacuum. Newly synthesized cefoperazone metal-based complexes were characterized by spectroscopic methods.

[Cd( $\left.\mathbf{H}_{\mathbf{2}} \mathbf{O}\right)(\mathbf{C F P}) \mathbf{C I}$ ]: Beige solid; m.p.: $193^{\circ} \mathrm{C}$. FTIR $(\mathrm{KBr}): v_{\max } 3450(\mathrm{OH}), 3252$ (br. m.), $2980\left(\mathrm{NH}_{2}\right)$ 1667 (Amide $\mathrm{C}=\mathrm{O}$ ), 1607 (Acid M-OOC), 801 (M-N), $761 \mathrm{~cm}^{-1}$ (M-O). Anal. Calcd. (810.54): C, 37.05; $\mathrm{H}$, 3.48; $N$, 15.55; Cd, 13.87. Found: $C, 37.09 ; \mathrm{H}, 3.53$; N, 15.50; Cd, 13.90 .

[Co( $\left.\mathbf{H}_{\mathbf{2}} \mathbf{O}\right)(\mathbf{C F P}) \mathbf{C I}$ ]: Dark brown solid; m.p.: $213^{\circ} \mathrm{C}$. FTIR (KBr): $v_{\max } 3486(\mathrm{OH}), 3386,2984\left(\mathrm{NH}_{2}\right), 1661$ (Amide $\mathrm{C}=\mathrm{O}), 1610$ (Acid $\mathrm{M}-\mathrm{OOC}), 755 \mathrm{~cm}^{-1}(\mathrm{M}-\mathrm{O})$. Anal. Calcd. (757.06): C, 39.66; H, 3.73; N, 16.65; Co, 7.78. Found: C, 39.70; H, 3.75; N, 16.63; Co, 7.85 .

[Cu( $\left.\mathbf{H}_{\mathbf{2}} \mathbf{O}\right)$ (CFP)CI]: Brown solid; m.p.: $220^{\circ} \mathrm{C}$. FTIR $(\mathrm{KBr}): v_{\max } 3440(\mathrm{OH}), 3249,3134\left(\mathrm{NH}_{2}\right), 1774$ (Amide $\mathrm{C}=\mathrm{O}$ ), 1618 (Acid $\mathrm{M}-\mathrm{OOC}), 751 \mathrm{~cm}^{-1}(\mathrm{M}-\mathrm{O})$. Anal. Calcd. (761.67): C, 39.42; H, 3.71; N, 16.55; $\mathrm{Cu}, 8.34$. Found: $\mathrm{C}, 39.40 ; \mathrm{H}, 3.78 ; \mathrm{N}, 16.65 ; \mathrm{Cu}$, 8.33 .

[Fe( $\left(\mathrm{H}_{\mathbf{2}} \mathbf{O}\right)_{\mathbf{2}}(\mathbf{C F P}) \mathrm{Cl}_{\mathbf{2}}$ ]: Black solid; m.p.: $201{ }^{\circ} \mathrm{C}$. FTIR (KBr): $v_{\max } 3208$ (br. S, OH), $2980\left(\mathrm{NH}_{2}\right), 1661$ (Amide $\mathrm{C}=\mathrm{O}$ ), 1612 (Acid M-OOC), $805(\mathrm{M}-\mathrm{N}), 761$ $\mathrm{cm}^{-1}$ (M-O). Anal. Calcd. (807.44): C, 37.19; H, 3.74; $\mathrm{N}, 15.61 ; \mathrm{Fe}, 6.92$. Found: $\mathrm{C}, 37.20 ; \mathrm{H}, 3.75 ; \mathrm{N}$, 15.60; Fe, 6.90

[Ni( $\left.\left.\mathbf{H}_{\mathbf{2}} \mathbf{O}\right)(\mathbf{C F P}) \mathbf{C l}\right]$ : Light brown solid; m.p.: $220^{\circ} \mathrm{C}$. FTIR (KBr): $v_{\max } 3281$ (br. s, OH), $2984\left(\mathrm{NH}_{2}\right), 1667$ (Amide $\mathrm{C}=0$ ), 1609 (Acid $\mathrm{M}-\mathrm{OOC}), 761 \mathrm{~cm}^{-1}$ (M-O). Anal. Calcd. (756.82): C, 39.67; H, 3.73; N, 16.66; $\mathrm{Ni}, 7.76$. Found: $\mathrm{C}, 39.70 ; \mathrm{H}, 3.70 ; \mathrm{N}, 16.70 ; \mathrm{Ni}$, 7.71 .

[Ru( $\left.\mathbf{H}_{\mathbf{2}} \mathbf{O}\right)_{\mathbf{2}}(\mathbf{C F P}) \mathbf{C l}_{\mathbf{2}}$ ]: Black solid; m.p.: $305{ }^{\circ} \mathrm{C}$. FTIR (KBr): $v_{\max } 3205$ (br. s, OH), $2980(\mathrm{NH} 2), 1657$ (Amide $\mathrm{C}=\mathrm{O}$ ), 1617 (Acid $\mathrm{M}-\mathrm{OOC}$ ), $822(\mathrm{M}-\mathrm{N}), 763$ $\mathrm{cm}^{-1}(\mathrm{M}-\mathrm{O})$. Anal. Calcd. (852.67): C, 35.22; H, 3.55; $\mathrm{N}, 14.78 ; \mathrm{Ru}, 11.85$. Found: $\mathrm{C}, 35.25 ; \mathrm{H}, 3.55 ; \mathrm{N}$, 14.80; Ru, 11.80 .

[Zn( $\left.\mathbf{H}_{\mathbf{2}} \mathbf{O}\right)$ (CFP)CI]: Beige solid; m.p.: $181{ }^{\circ} \mathrm{C}$. FTIR $(\mathrm{KBr}): v_{\max } 3440$ (br. $\left.\mathrm{m}, \mathrm{OH}\right), 3281,2944$ (NH2), 1667 (Amide $\mathrm{C}=\mathrm{O}$ ), 1597 (Acid M-OOC), $779(\mathrm{M}-\mathrm{N}$ ) $760 \mathrm{~cm}^{-1}$ (M-O). Anal. Calcd. (763.54): C, 39.33; H,
3.70; N, 16.51; Zn, 8.57. Found: C, 39.30; H, 3.71; $\mathrm{N}, 16.54 ; \mathrm{Zn}, 8.53$.

\section{Pt(II) complex of cefoperazone}

CEFOBID (668 mg, $1 \mathrm{mmol}$ ) was dissolved in 1.00 $\mathrm{mL}$ of deionized water and $20.0 \mathrm{~mL}$ of ethanol in $100 \mathrm{~mL}$ two-necked round-bottomed flask by heating the reaction mixture up to reflux temperature on a magnetic stirrer. To the prepared solution was introduced $\mathrm{PtCl}_{2}(266 \mathrm{mg}, 1 \mathrm{mmol}$ ) in $2.00 \mathrm{~mL}$ of DMSO. Resulting mixture was refluxed for $8 \mathrm{~h}$ and the completion of reaction was checked by TLC. After that the mixture was filtered off and the solid residue was successively washed with deionized water, $\mathrm{MeOH}$, and diethyl ether. The product was dried under vacuum.

[Pt( $\left.\mathbf{H}_{\mathbf{2}} \mathbf{O}\right)(\mathbf{C F P}) \mathbf{C I}$ ]: Brown solid; m.p.: $119{ }^{\circ} \mathrm{C}$. FTIR $(\mathrm{KBr})$ : $v_{\max } 3446$ (br. s, OH), 3243, $3010\left(\mathrm{NH}_{2}\right), 1676$ (Amide $\mathrm{C}=\mathrm{O}$ ), 1626 (Acid $\mathrm{M}-\mathrm{OOC}), 778(\mathrm{M}-\mathrm{N}), 718$ $\mathrm{cm}^{-1}$ (M-O). Anal. Calcd. (893.21): C, 33.62; H, 3.16; $\mathrm{N}, 14.11$; Pt, 21.84. Found: C, 33.60; H, 3.15; N, 14.10; Pt, 21.89.

\section{Pd(II) complex of cefoperazone}

To a solution of $\mathrm{Pd}\left(\mathrm{CH}_{3} \mathrm{COOH}\right)_{2}(325 \mathrm{mg}, 1 \mathrm{mmol})$ in $20.0 \mathrm{~mL}$ of acetic acid was added of CEFOBID (668 $\mathrm{mg}, 1 \mathrm{mmol})$. Resulting mixture was stirred at 40 ${ }^{\circ} \mathrm{C}$ for $8 \mathrm{~h}$. After that the mixture was filtered off and the solid residue was successively washed with deionized water, $\mathrm{MeOH}$, and diethyl ether. The product was dried under vacuum.

[Pd( $\left.\mathbf{H}_{\mathbf{2}} \mathbf{O}\right)$ (CFP)(OAC)]: Brown solid; m.p.: > 300 ${ }^{\circ} \mathrm{C}$. FTIR $(\mathrm{KBr}): v_{\max } 3201$ (br. s., OH), $3059\left(\mathrm{NH}_{2}\right)$, 1763 (Amide $\mathrm{C}=\mathrm{O}), 1587$ (Acid $\mathrm{M}-\mathrm{OOC}$ ), $825(\mathrm{M}-\mathrm{N}$ ), $755 \mathrm{~cm}^{-1}$ (M-O). Anal. Calcd. (828.14): C, 39.16; $\mathrm{H}$, 3.77; N, 15.22; Pd, 12.85. Found: C, 39.15; H, 3.80; N, 15.18; Pd, 12.81 .

\section{Computational details}

Geometry optimizations, frequency analyses, molecular electrostatic potential map (MEP), and frontier molecular orbital (FMO) calculations were performed at DFT B3LYP (Becke, 3-parameter, LeeYang-Parr) level of theory using $6-31+G(d, p)$ basis set as implemented in Gaussian 09 Rev.D.01 package (6) owing to the good performance of the functional in the prediction of geometries $(7,8)$. A scaling factor of 0.9632 suggested by Irikura et al. was applied to calculate the spectra of both cefoperazone and its sodium salt (9). The visualization and analysis of electronic wavefunctions were realized with GaussView5 (10), Avogadro 1.1.1 (11), Multiwfn (12) and GaussSum 3.0 (13) softwares. The minima of the investigated compounds were verified by analyzing the harmonic vibrational frequencies using analytical second derivatives, which have NIMAG $=0$. Incorporation of the solvent effects was realized by using self-consistent reaction field with the integral equation formalism of the Polarizable Continuum 
Model (IEFPCM) $(14,15,16)$ as implemented in Gaussian 09 package. DMSO $(\varepsilon=46.826)$ was selected as a solvent to mimic the UV-Vis measurement conditions. TD-DFT B3LYP/6$31+G(d, p)$ calculations including solvent effects (DMSO) were applied to obtain vertical excitations.

\section{Antimicrobial studies}

The in-vitro investigation of antimicrobial activity of the metal-based complexes of was performed using Candida albicans (fungus), Staphylococcus aureus 65383, Escherichia coli ATCC 298925, Klebsiella pneumoniae FMC 5, Bacillus megaterium DSM 32, Kluvyeromyces fragilis $A$ 230, Mycobacterium smegmatis CCM 2067, Bacillus cereus EÜ 2630, Pseudomonas aeruginosa 9027, Enterococcus cloacea ATCC 13047, Micrococcus luteus LA 2971, and Saccharomyces cerevisiae WET 136 (fungus), using agar well diffusion method. Bacterial strains and fungi were incubated at $37 \pm 0.1{ }^{\circ} \mathrm{C}$ in nutrient agar medium and at $25 \pm$ $0.1{ }^{\circ} \mathrm{C}$ in dextrose, respectively, for $24 \mathrm{~h}$. $100 \mu \mathrm{L}$ of these solutions were taken into Petri dishes $(9 \mathrm{~cm})$. Later, Müller Hinton and dextrose agars, sterilized in one balloon and cooled down to $45-50{ }^{\circ} \mathrm{C}$, were portioned to $15 \mathrm{~mL}$ of sterilized Petri dishes homogenously. In addition to these Petri dishes, $500 \mu \mathrm{g}$ of synthesized compounds was added to 6 $\mathrm{mL}$ of sterilized test plates. These prepared test plates were introduced to agars. Diameters of inhibition zones, indicating the activity of compounds, were recorded (17).

\section{RESULTS AND DISCUSSION}

\section{Synthesis and Characterization}

Cefoperazone-metal-based complexes were achieved by refluxing the reaction mixture containing $1 \mathrm{mmol}$ of CFP, dissolved in $25 \mathrm{~mL}$ of $\mathrm{H}_{2} \mathrm{O} / \mathrm{MeOH}(1: 4, v / \mathrm{v})$, and $1 \mathrm{mmol}$ of corresponding metal chloride salts $\left(\mathrm{CuCl}_{2} \cdot 2 \mathrm{H}_{2} \mathrm{O}, \mathrm{CoCl}_{2} \cdot 6 \mathrm{H}_{2} \mathrm{O}\right.$, $\mathrm{NiCl}_{2} \cdot 6 \mathrm{H}_{2} \mathrm{O}, \mathrm{ZnCl}_{2} \cdot 2 \mathrm{H}_{2} \mathrm{O}, \mathrm{CdCl}_{2}, \mathrm{FeCl}_{3} \cdot 6 \mathrm{H}_{2} \mathrm{O}$ and $\mathrm{RuCl}_{3} \cdot 3 \mathrm{H}_{2} \mathrm{O}$ ) in $10 \mathrm{~mL}$ of $\mathrm{MeOH}$ for $24 \mathrm{~h}$ in moderate to good yields (50-70\%). In case of Pt(II) complex, $\mathrm{PtCl}_{2}$ was dissolved in $2 \mathrm{~mL}$ of dimethyl sulfoxide (DMSO) and the resulting solution was refluxed for $8 \mathrm{~h}$ rendering the target $\mathrm{Pt}(\mathrm{II})$-based complex in $59 \%$ yield. Moreover, synthesis of Pd(II) complex was realized by considering $\mathrm{Pd}(\mathrm{OAc})_{2}$ salt dissolved in $20 \mathrm{~mL}$ of $\mathrm{AcOH}$. The mixture was heated up to $40{ }^{\circ} \mathrm{C}$ for $8 \mathrm{~h}$ to provide the required $\mathrm{Pd}(\mathrm{II})$ complex in $57 \%$ yield.

IR spectroscopic characterization of all the synthesized metal based complexes involves analysis of the vibrational modes attributed to the coordination of functional units to metal centers owing to the similarity of the IR spectrum of cefoperazone to those of its complexes. Vibrational frequency of the ring carbonyl unit shifts to higher wave numbers as a result of increase in strain of the ring. Therefore, the lactam and the 2,3piperazinedione carbonyl vibrations show up around 1710 and $1650 \mathrm{~cm}^{-1}$, respectively, in the spectra of cefoperazone and its metal-based complexes (18). The amide carbonyl band of cefoperazone is at $1756 \mathrm{~cm}^{-1}$ while metal complexation shifted the corresponding vibrational bands to lower wavenumbers at around $1670 \mathrm{~cm}^{-1}$ indicative of coordination of metal to oxygen (19). On the other side, second amide carbonyl band appears in higher frequencies indicating lack of contribution of the nitrogen atom to the coordination (20). As a result, IR spectroscopic analyses depict the coordination of metals to cefoperazone ligand via oxygens of the amide carbonyl groups. The lactam and piperazinedione carbonyl groups demonstrated the absence of any significant shift of vibrational bands in metal coordination illustrating the lack of coordination with lactam and piperazinedione carbonyl units. The stretching vibrations of metal nitrogen bond in the range of $778-825 \mathrm{~cm}^{-1}$ supports the coordination of tetrazole unit to the metal ion via the nitrogen atom except than the $\mathrm{Co}(\mathrm{II}), \mathrm{Cu}(\mathrm{II})$ and $\mathrm{Ni}$ (II) complexes. Moreover, the $\mathrm{N}-\mathrm{H}$ stretching vibrations of amide groups in cefoperazone appear at $3286 \mathrm{~cm}^{-1}$, which slightly shifted in the metal based complexes pointing out the non-coordinated free units $(5,21)$. According to analyses of vibrational frequencies, metal coordination involves one tetrazole nitrogen, two amide oxygens and one carboxylate oxygen of cefoperazone, that is, cefoperazone is a tetradentate chelating agent in metal complexes excluding $\mathrm{Co}(\mathrm{II}), \mathrm{Cu}(\mathrm{II})$ and $\mathrm{Ni}(\mathrm{II})$ complexes (Figure 3 and Figure 5). Unlike the other metals, $\mathrm{Cu}$ and $\mathrm{Ni}$ do not coordinate to nitrogen of tetrazole ring in a tetrahedral structure (3), in which cefoperazone behaves as tridentate chelating agent.

Thermal analyses of metal-based complexes demonstrated endothermic decompositions at around $100{ }^{\circ} \mathrm{C}$ indicating the loss of water from complexes in the case of $\mathrm{Ru}(\mathrm{III})(4 \%)$ and $\mathrm{Pt}(\mathrm{II})$ (4\%) complexes, and the loss of water and $\mathrm{Cl}$ anions together with one of the tetrazole units (13\%) from $\mathrm{Ni}(\mathrm{II})$ complex owing to the free conformation of tetrazole units. The loss of the second tetrazole was observed at around $175{ }^{\circ} \mathrm{C}$. They moreover depicted the stability of the complexes up to 160 and $200{ }^{\circ} \mathrm{C}$ for $\mathrm{Ru}(\mathrm{III})$ and $\mathrm{Pt}(\mathrm{II})$ complexes, respectively (Figure 2 ). 

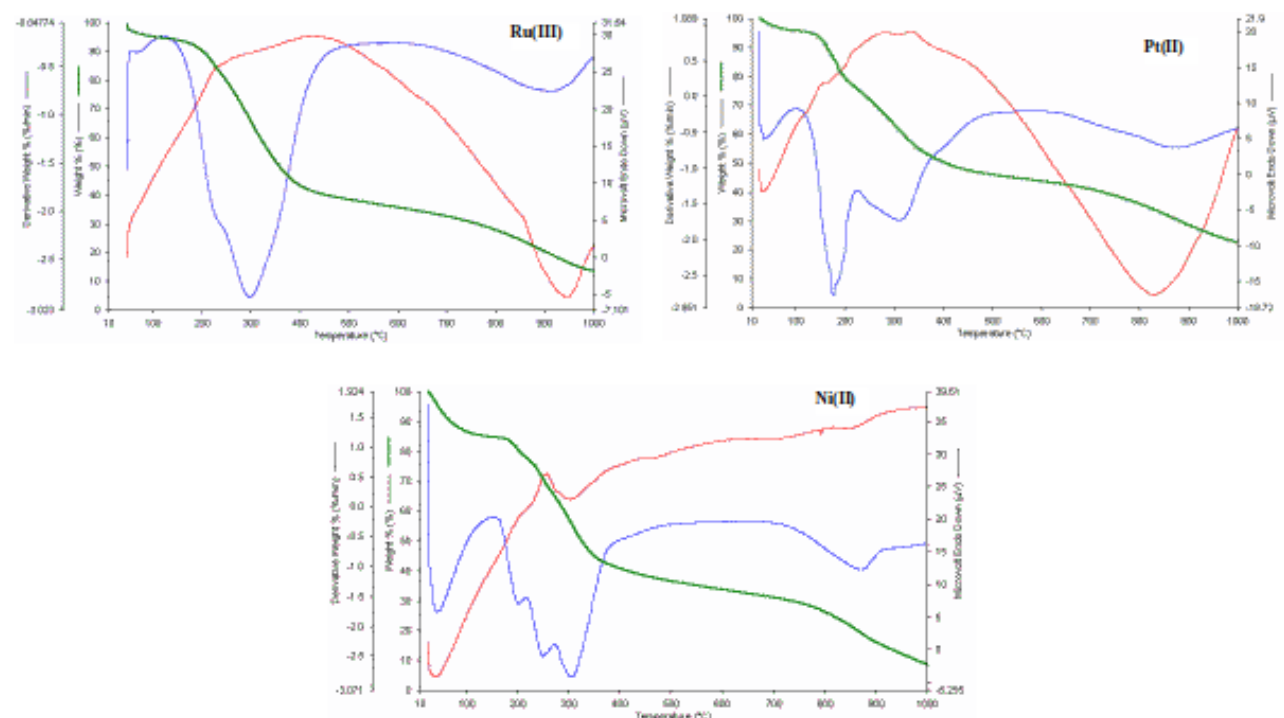

Figure 2. DTA-TG thermograms of $\mathrm{Ru}(\mathrm{III}), \mathrm{Pt}(\mathrm{II})$ and $\mathrm{Ni}(\mathrm{II})$ cefoperazone complexes.

Conductivity measurements realized in $1 \times 10^{-3} \mathrm{M}$ of DMSO at room temperature resulted in that the solutions of all the complexes are non-electrolytes, involving the coordination of chloride ion to the metal center, except than $\mathrm{Co}(\mathrm{II}), \mathrm{Cu}(\mathrm{II})$ and $\mathrm{Ni}(\mathrm{II})$ complexes which have conductivities $(\Lambda)$ of 211 , 161 and $167 \Omega^{-1} \mathrm{~cm}^{2} \mathrm{~mol}^{-1}$. The obtained magnetic moments $\left(\mu_{\text {eff }}\right)$ indicate high spin ions in octahedral fields Fe(III) complex has a magnetic moment of 5.30 B.M. which is well in alignment with high spin $\mathrm{d}^{5}$ system possessing five unpaired electrons. $\mu_{\text {eff }}$ value of Co(II) complex was measured to be 4.26 B.M. suggesting $\mathrm{Co}(\mathrm{II})$ in five or six coordinate geometry with a high spin configuration. $\mu_{\text {eff }}$ value of $\mathrm{Cu}(\mathrm{II})$ complex was recorded as 1.83 B.M., matching well with the calculated magnetic moment of 1.73 B.M. for a $d^{9}$ configuration (5). $\mathrm{Ru}(\mathrm{III})$ shows a low-spin octahedral geometry and its magnetic moment was measured to be 1.85 B.M.

The Job-Plot constructed performing three independent titrations of $\mathrm{Fe}(\mathrm{III})$ cation with cefoperazone anion indicated that the molar ratio of $\mathrm{Fe}(\mathrm{III})$ and CFP is 1 , indicative of $1: 1$ complex formation (Figure 4).

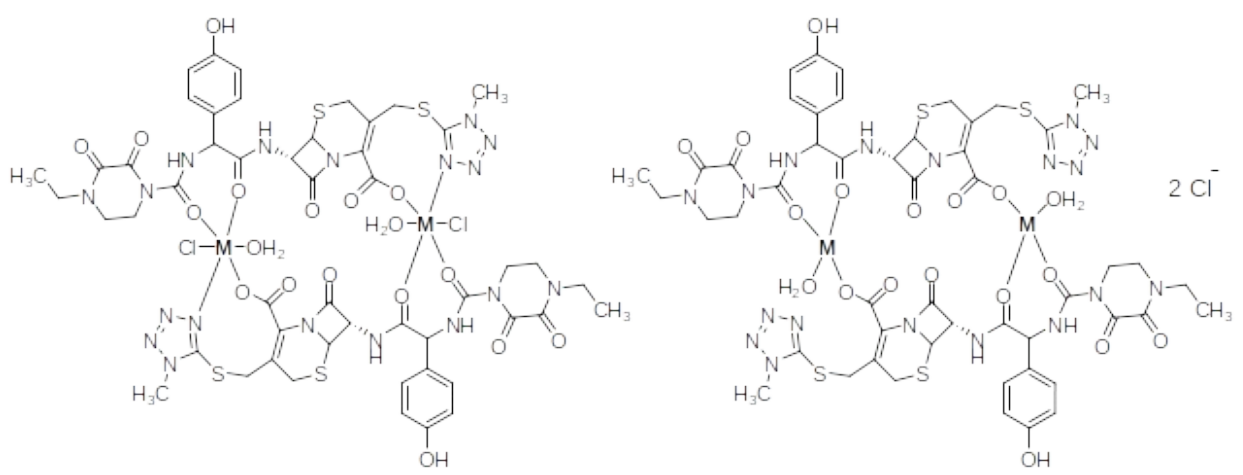

Figure 3. Octahedral metal(II) complexes of cefoperazone apart from $\mathrm{Co}(\mathrm{II}), \mathrm{Cu}$ (II) and $\mathrm{Ni}(\mathrm{II})$ having lack of coordination to tetrazole nitrogen in tetrahedral structure accompanied by chloride anion. 


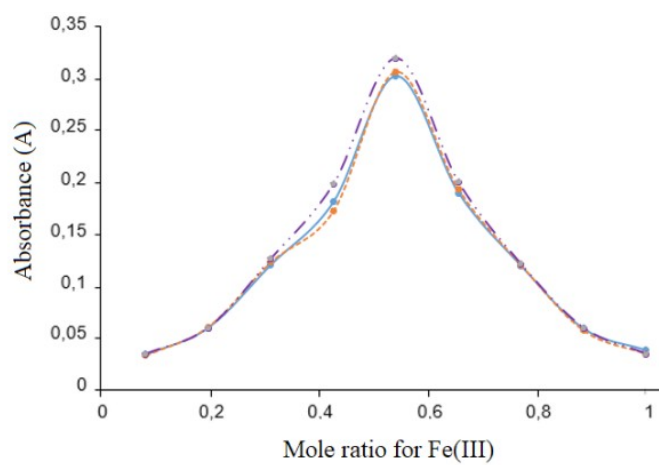

Figure 4. Job plot constructed using results from three independent titrations of Fe(III) cation with cefoperazone anion.

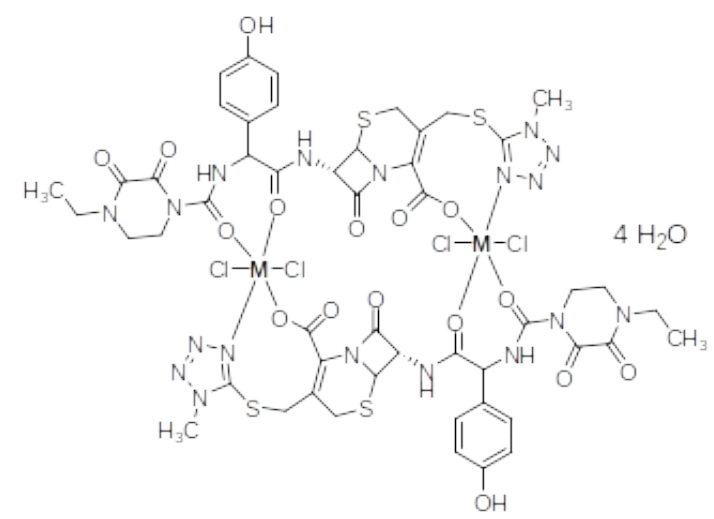

Figure 5. $\mathrm{Fe}(\mathrm{III})$ and $\mathrm{Ru}(\mathrm{III})$ complexes of cefoperazone.

\section{Optical investigations}

Optical properties of the cefoperazone and its metal-based complexes were investigated in $1 \times 10^{-4}$ $M$ solution of DMSO, rendering absorption maxima between 250-270 $\mathrm{nm}$ attributed to a $\pi \rightarrow \pi^{*}$ transition emerging from the NC-S moiety (22). While the absorption bands of tetrazole units were detected at 290-320 nm and assigned to the $\pi \rightarrow \pi^{*}$ electronic transitions, the recorded UV-Vis bands at around $370 \mathrm{~nm}$ originated from sulfur atoms and characterized as the $n \rightarrow \pi^{*}$ type electronic transitions (23). The almost unsaturated structure of cefoperazone results in the intense UV absorption accompanied by a tail in the visible region, which impedes detection of the relatively week d-d electronic transitions of the cobalt(II) and iron(II) ions. The Co(II) complex demonstrated a broad absorption band at $625 \mathrm{~nm}$ assigned to a d-d electronic transition. $\mathrm{Pt}(\mathrm{II}), \mathrm{Pd}(\mathrm{II})$ and $\mathrm{Cd}(\mathrm{II})$ cefoperazone complexes had the smallest $\lambda_{\max }$ values of 315,345 and $374 \mathrm{~nm}$, respectively, whereas the absorption maxima of $\mathrm{Zn}(\mathrm{II}), \mathrm{Ru}(\mathrm{III})$, $\mathrm{Co}(\mathrm{II})$ and $\mathrm{Fe}$ (III) CFP complexes were detected between 528 and $671 \mathrm{~nm}$. The highest $\lambda_{\max }$ values were recorded for complexes of $\mathrm{Cu}(\mathrm{II})$ as $730 \mathrm{~nm}$ and $\mathrm{Ni}(\mathrm{II})$ as $853 \mathrm{~nm}$.

\section{Computation}

The optimized geometries and vibrational spectra of cefoperazone and cefoperazone sodium at B3LYP level are given in Figure 6. The predicted vibrational spectrum of the sodium salt is well in alignment with the experimentally recorded spectrum (24). The estimated vibrations are listed as; 3685 (phenolic -OH stretching), 3491 (-NH stretching adjacent to lactam), $3371 \mathrm{~cm}^{-1}(-\mathrm{NH}$ stretching proximate to piperazinedione), 1723 $(\mathrm{C}=\mathrm{O}$ stretching in lactam), 1706 and 1697 (C=O stretching in piperazinedione), $1583 \quad(\mathrm{C}=\mathrm{O}$ stretching of (CO-) and 1494 and $1487 \mathrm{~cm}^{-1}$ (bending of - $\mathrm{NH}$ groups). 


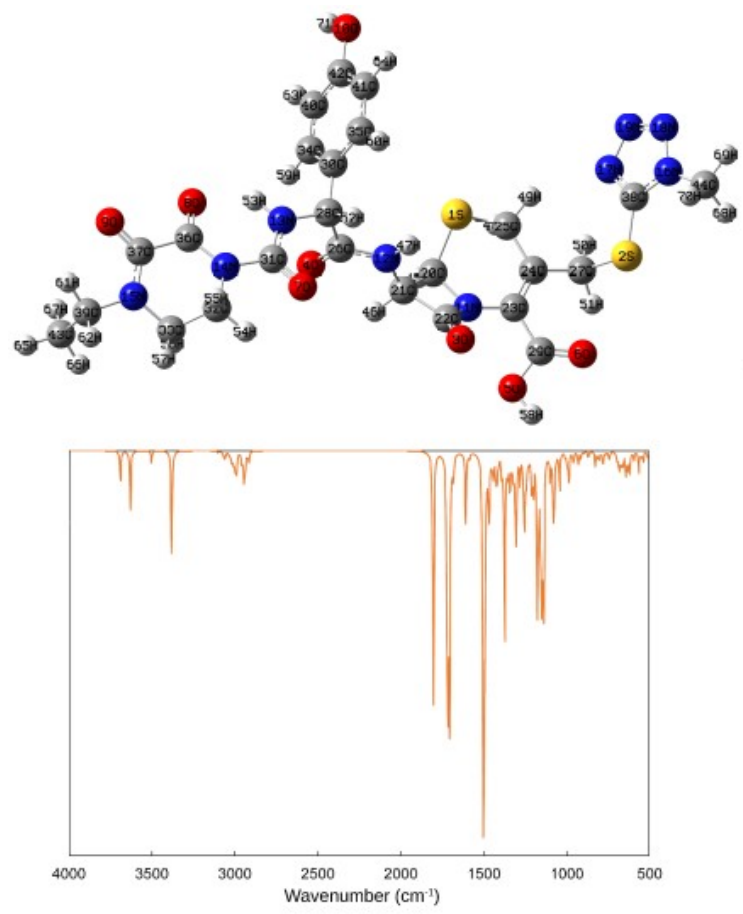

(a)

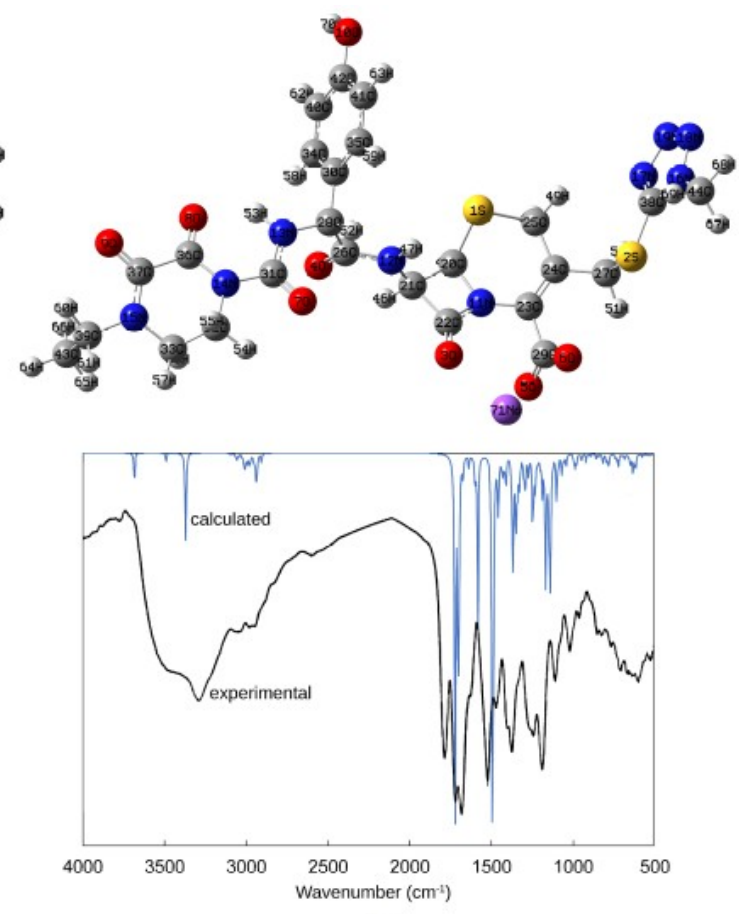

(b)

Figure 6. Optimized structures and vibrational spectra of (a) cefoperazone and (b) cefoperazone sodium at $B 3 L Y P / 6-31+G(d, p)$ level.

Molecular Electrostatic Potential (MEP) maps illustrate the charge distributions of molecules and give information about the electron rich and electron deficient parts of the investigated molecules. MEP maps of cefoperazone and cefoperazone sodium obtained at the same level of

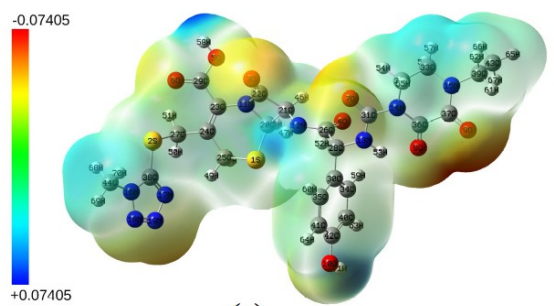

(a) theory are depicted in Figure 7. For both cefoperazone and cefoperazone sodium, it was observed that negative charges were mainly located on the carbonyl oxygens in both calculated molecules, whereas the positive charge was exclusively found on the sodium atom.

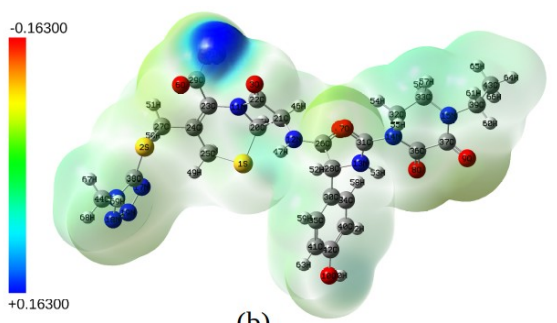

(b)

Figure 7. MEP maps of cefoperazone (a) and cefoperazone sodium (b).

Frontier molecular orbitals (FMO) of cefoperazone and cefoperazone sodium, and the predicted HOMO-LUMO gaps are demonstrated in Figure 8. The estimated HOMO-LUMO gap of cefoperazone sodium is slightly larger than that of cefoperazone by $0.12 \mathrm{eV}$ emerging from the destabilization of the FMO by sodium cation. Destabilization significantly reflected to the LUMO of salt results in higher laying HOMO and LUMO with energies of -6.48 and $-2.06 \mathrm{eV}$ compared to those of cefoperazone with -
6.56 and $-2.27 \mathrm{eV}$, respectively. Hence, HOMOLUMO gap increases in sodium salt. While HOMO is mainly located on phenol unit in cefoperazone, LUMO is observed on lactam and $\mathrm{COO}^{-}$substituted six-membered ring. However, HOMO is lying on the sodium coordinated fragment spreading over the tetrazole unit of cefoperazone salt and LUMO is mainly on piperazinedione group with a small contribution of the adjacent amide unit. 


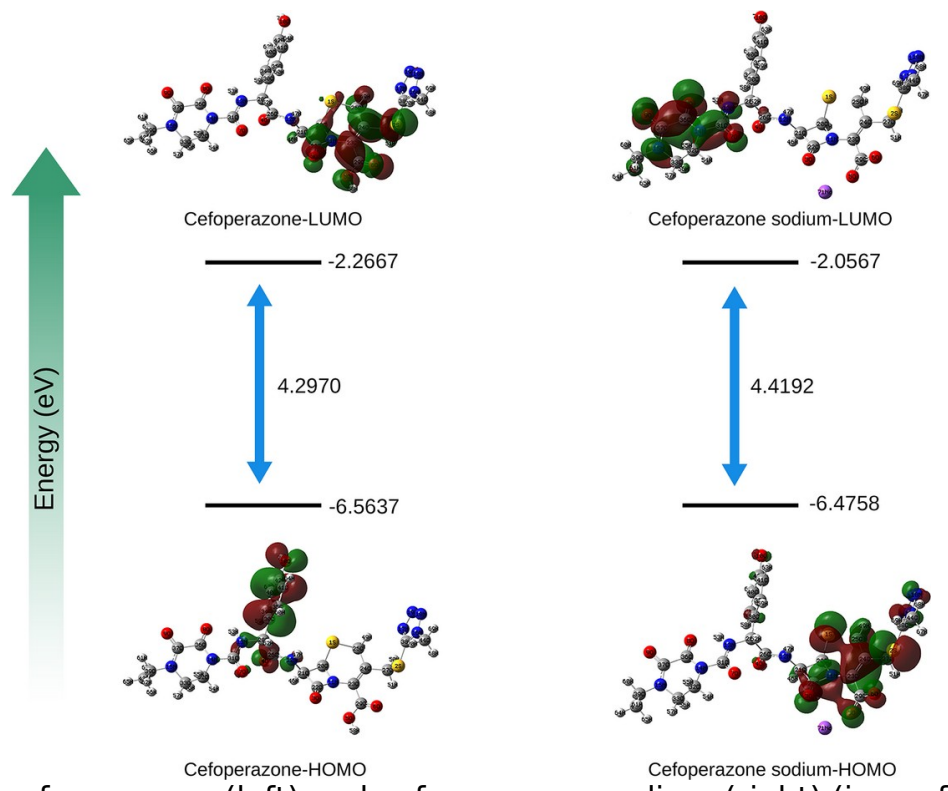

Figure 8. FMOs of cefoperazone (left) and cefoperazone sodium (right) (isosurface values $=0.02$ ).

The vertical excitation energies and UV-Vis spectra, predicted from the time-dependent DFT calculations by incorporation of solvent effect (DMSO), are given in Table 1 and Figure 9, respectively. The calculated spectral properties of cefoperazone and cefoperazone sodium are in good agreement with the recorded absorption values. Coordination of $\mathrm{Na}^{+}$led to the bathochromic shift from 285 to $294 \mathrm{~nm}$. The $\lambda_{\max }$ values of cefoperazone and cefoperazone sodium arise from the HOMO-3 $\rightarrow$ LUMO (83\%) and HOMO $\rightarrow$ LUMO+1 (99\%) transitions, respectively.

Table 1. Excited state electronic transitions obtained from (IEFPCM:DMSO)-TD-B3LYP/6-31+G(d,p) level computations (H: HOMO, L: LUMO, F: Oscillatory strength).

\begin{tabular}{lcccl}
\hline Compound & $\begin{array}{c}\boldsymbol{\lambda}_{\text {abs }} \\
(\mathbf{n m})\end{array}$ & $\begin{array}{c}\text { Energy } \\
(\mathbf{e V})\end{array}$ & $\boldsymbol{F}$ & \multicolumn{1}{c}{ Major contribution (\%) } \\
\hline Cefoperazone & 285 & 4.35 & 0.213 & $\mathrm{H}-3 \rightarrow \mathrm{L}(83)$ \\
& 309 & 4.01 & 0.036 & $\mathrm{H}-2 \rightarrow \mathrm{L}(85) ; \mathrm{H}-2 \rightarrow \mathrm{L}(85)$ \\
Cefoperazone & 331 & 3.74 & 0.049 & $\mathrm{H}-\mathrm{L} \rightarrow \mathrm{L}(90)$ \\
Sodium & 294 & 4.22 & 0.129 & $\mathrm{H} \rightarrow \mathrm{L}+1(99) ; \mathrm{H}-4 \rightarrow \mathrm{L}+1(19) ; \mathrm{H}-2 \rightarrow \mathrm{L}+1(12)$ \\
& 298 & 4.16 & 0.014 & $\mathrm{H}-2 \rightarrow \mathrm{L}+1(47) ; \mathrm{H} \rightarrow \mathrm{L}(37) ; \mathrm{H} \rightarrow \mathrm{L}+1(10)$ \\
& 299 & 4.15 & 0.024 & $\mathrm{H} \rightarrow \mathrm{L}(56) ; \mathrm{H}-2 \rightarrow \mathrm{L}+1(27) ; \mathrm{H} \rightarrow \mathrm{L}+1(11)$ \\
\hline
\end{tabular}



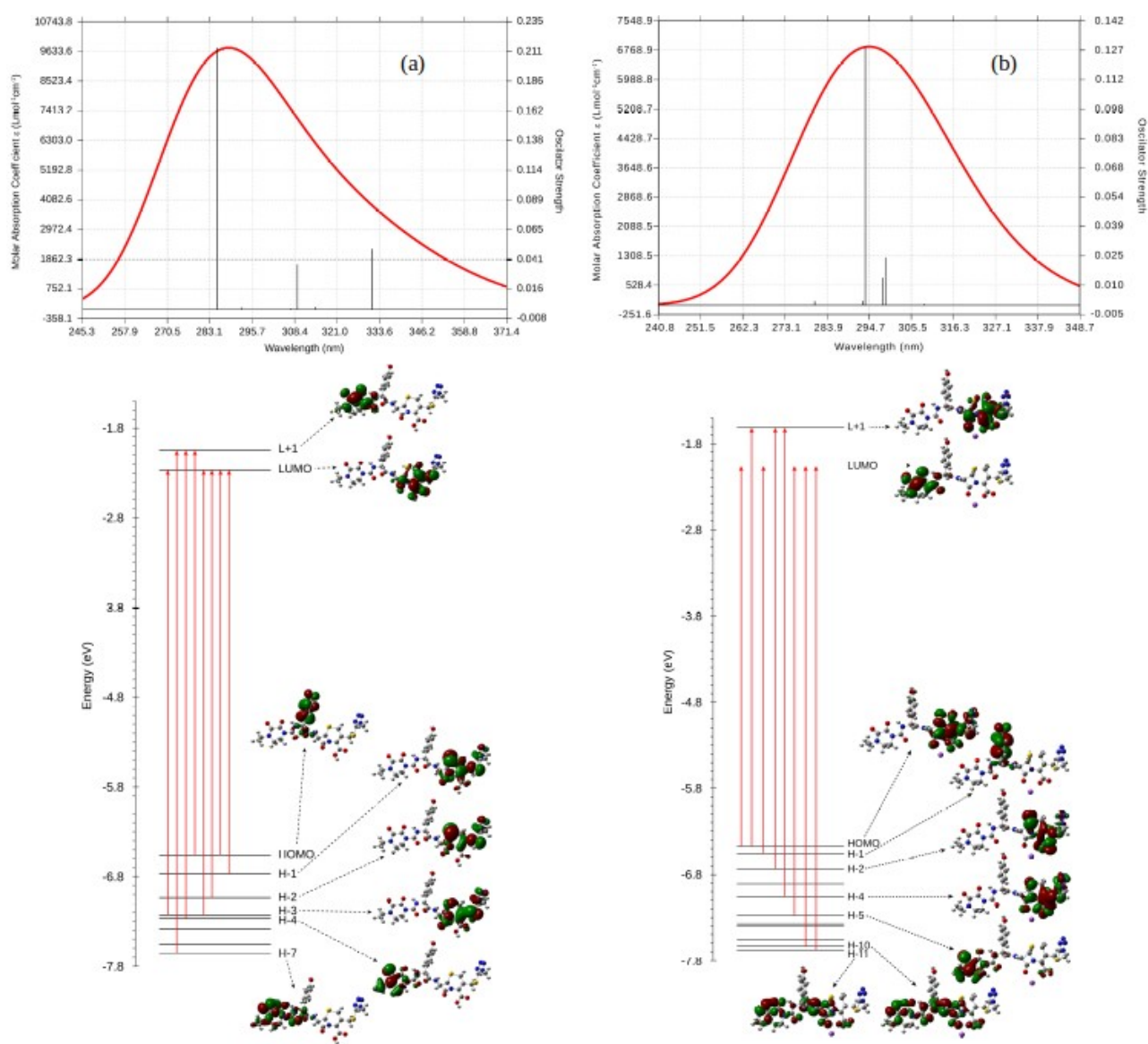

Figure 9. Calculated UV-Vis Spectra and electronic transitions of cefoperazone (a) and cefoperazone sodium (b).

\section{Antimicrobial studies}

The susceptibility of some bacteria and fungi against cefoperazone and its metal-based complexes was corroborated by measuring the diameter of inhibition. Cefoperazone and its complexes gave rise to the bactericide diameters of larger than $20 \mathrm{~mm}$ indicative of a good activity $(25,26)$. The results are listed in Table 2 , depicting different behavior of the metal-based complexes with respect to cefoperazone.

Table 2. Antibacterial activity of cefoperazone and its metal-based complexes against some bacteria and

\begin{tabular}{|c|c|c|c|c|c|c|c|c|c|c|c|c|}
\hline & & & & & & & & & & & & \\
\hline Compound & 1 & 2 & 3 & 4 & 5 & 6 & 7 & 8 & 9 & 10 & 11 & 12 \\
\hline$\overline{\text { CFP }}$ & 9 & 5 & 8 & 10 & 7 & 9 & 4 & - & - & - & - & 7 \\
\hline$\left[\mathrm{Cd}\left(\mathrm{H}_{2} \mathrm{O}\right)(\mathrm{CFP}) \mathrm{Cl}\right]$ & 38 & 35 & 34 & 12 & 7 & 35 & 8 & 8 & 7 & 7 & 14 & 9 \\
\hline$\left[\mathrm{Co}\left(\mathrm{H}_{2} \mathrm{O}\right)(\mathrm{CFP}) \mathrm{Cl}\right]$ & 30 & 34 & 30 & 8 & 8 & 29 & 15 & 9 & - & 10 & - & 28 \\
\hline$\left[\mathrm{Cu}\left(\mathrm{H}_{2} \mathrm{O}\right)(\mathrm{CFP}) \mathrm{Cl}\right]$ & 23 & 20 & 22 & 8 & 12 & 25 & 14 & 11 & - & 11 & 7 & 19 \\
\hline$\left[\mathrm{Fe}\left(\mathrm{H}_{2} \mathrm{O}\right)_{2}(\mathrm{CFP}) \mathrm{Cl}_{2}\right]$ & 20 & 15 & 20 & - & 7 & 33 & 16 & 11 & 16 & 9 & - & 36 \\
\hline$\left[\mathrm{Ni}\left(\mathrm{H}_{2} \mathrm{O}\right)(\mathrm{CFP}) \mathrm{Cl}\right]$ & 15 & 16 & 20 & 8 & 10 & 30 & 10 & 12 & 7 & 10 & - & 24 \\
\hline$\left[\mathrm{Pt}\left(\mathrm{H}_{2} \mathrm{O}\right)(\mathrm{CFP}) \mathrm{Cl}\right]$ & 14 & 10 & 17 & 13 & 19 & 16 & 12 & 20 & 7 & 12 & - & 17 \\
\hline$\left[\mathrm{Pt}\left(\mathrm{H}_{2} \mathrm{O}\right)(\mathrm{CFP}) \mathrm{Cl}\right]$ & 21 & 18 & 21 & 26 & 20 & 30 & 25 & 20 & 24 & 8 & 12 & 20 \\
\hline$\left[\mathrm{Ru}\left(\mathrm{H}_{2} \mathrm{O}\right)_{2}(\mathrm{CFP}) \mathrm{Cl}_{2}\right]$ & 25 & 14 & 20 & 23 & 14 & 23 & 16 & 15 & 20 & 15 & 14 & 24 \\
\hline$\left[\mathrm{Zn}\left(\mathrm{H}_{2} \mathrm{O}\right)(\mathrm{CFP}) \mathrm{Cl}\right]$ & 23 & 35 & 34 & 7 & 8 & 24 & 22 & 13 & 19 & 12 & - & 37 \\
\hline
\end{tabular}

Bacteria and fungi: 1) Candida albicans (fungus), 2) Staphylococcus aureus 65383, 3) Escherichia coli ATCC 298925, 4) Klebsiella pneumoniae FMC 5, 5) Bacillus megaterium DSM 32, 6) Kluvyeromyces fragilis A 230, 7) Mycobacterium smegmatis CCM 2067, 8) Bacillus cereus EÜ 2630, 9) Pseudomonas aeruginosa 9027, 10) Enterococcus cloacea ATCC 13047, 11) Micrococcus luteus LA 2971, 12) Saccharomyces cerevisiae WET 136 (fungus).

While all metal complexes excluding $\mathrm{Pd}(\mathrm{II})$ demonstrated good activity against Escherichia coli
ATCC 298925 and Kluvyeromyces fragilis A 230, none of the compounds rendered good bactericidal 
activity against Bacillus megaterium DSM 32, Enterococcus cloacea ATCC 13047, and Micrococcus luteus LA 2971. Co(II), Cu(II), Fe(III), $\mathrm{Ni}(\mathrm{II}), \mathrm{Zn}(\mathrm{II})$ demonstrated to be less active than free cefoperazone against Klebsiella pneumoniae FMC 5. The highest antibacterial activity was recorded by $\mathrm{Cd}(\mathrm{II})$ against Candida albicans, and $\mathrm{Fe}(\mathrm{III})$ and $\mathrm{Zn}(\mathrm{II})$ against Saccharomyces cerevisiae WET 136

\section{CONCLUSION}

Metal-based cefoperazones characterized to have 1:1 metal to antibiotic stoichiometry were synthesized and their spectroscopic analyses were performed. Their antimicrobial investigations illustrated good activities of all the metal complexes excluding $\mathrm{Pd}(\mathrm{II})$ against Escherichia coli ATCC 298925 and Kluvyeromyces fragilis $A 230$. The highest antibacterial activities were observed by $\mathrm{Cd}$ (II) against Candida albicans, and Fe(III) and Zn(II) against Saccharomyces cerevisiae WET 136. DFT computations were conducted to shed light on the electronic structure of cefoperazone and its sodium salt. Detailed analyses of the predicted results helped us get a glimpse of metal based cefoperazone complexes. Based on the results, it is stated that character of metal ion and of microorganism play important roles in efficiency of antibacterial activities.

\section{ACKNOWLEDGEMENTS}

The authors wish to thank TUBITAK (Project No: 105T371) for the financial support; Kahramanmaras Sutcu Imam University, Chemistry Department for laboratory environments; and Kahramanmaras Sutcu Imam University, Biology Department for cell culture studies. We thank the Istanbul Technical University for the laboratory (L105) facilities to redo the experiments. We are indebted to the Kocaeli University for the computer time provided.

\section{SUPPLEMENTARY INFORMATION}

IR spectra of cefoperazone and its metal-based complexes.

\section{REFERENCES}

1. Badr IHA, Saleh GA, Sayed SM, Nour El-Deen DAM. A Novel Membrane Sensor for Batch and Flow Injection Potentiometric Determination of Cefazolin Sodium in Pharmaceutical Preparations. Int. J. Electrochem. Sci. 2014;9:1621-36.

2. Percin-Ozkorucuklu S, Uka B, Yildirim-Bastemur G. Voltammetric analysis of cephalexin and cefazolin in pharmaceutical formulations and biological samples. Journal of the Turkish Chemical Society, Section A: Chemistry. 2019;6:217-24.
3. Masoud MS, Ali AE, Elasala GS, Kolkaila SA. Spectroscopic Studies and Thermal Analysis on Cefoperazone Metal Complexes. J. Chem. Pharm. Res. 2017;9:171-9.

4. Alekseev VG. Metal complexes of penicillins and cephalosporins. Pharm. Chem. J. 2012;45:679-97.

5. Anacona JR, Bravo A, Lopez ME. Cefoperazone metal complexes: synthesis and characterization. J. Chil. Chem. Soc. 2013;58:1520-3.

6. Frisch MJ, Trucks GW, Schlegel HB, Scuseria GE, Robb MA, Cheeseman JR, Scalmani G, Barone V, Petersson GA, Nakatsuji $\mathrm{H}$, Li X, Caricato $M$, Marenich AV, Bloino J, Janesko BG, Gomperts R, Mennucci B, Hratchian HP, Ortiz JV, Izmaylov AF, Sonnenberg JL, Williams-Young D, Ding F, Lipparini F, Egidi F, Goings J, Peng B, Petrone A, Henderson T, Ranasinghe D, Zakrzewski VG, Gao J, Rega N, Zheng G, Liang W, Hada M, Ehara M, Toyota K, Fukuda R, Hasegawa J, Ishida $M$, Nakajima $T$, Honda $\mathrm{Y}$, Kitao O, Nakai H, Vreven T, Throssell K, Montgomery JA Jr, Peralta JE, Ogliaro F, Bearpark MJ, Heyd JJ, Brothers EN, Kudin KN, Staroverov VN, Keith TA, Kobayashi R, Normand J, Raghavachari K, Rendell AP, Burant JC, lyengar SS, Tomasi J, Cossi M, Millam JM, Klene M, Adamo C, Cammi R, Ochterski JW, Martin RL, Morokuma K, Farkas O, Foresman JB, Fox DJ. Gaussian 09, Rev.D.01, Gaussian, Inc., Wallingford CT, 2013.

7. Ceylan BI.Oxovanadium(IV)-containing N2O2 chelate complex; crystal structure determination and DFT. Journal of the Turkish Chemical Society, Section A: Chemistry. 2016;3:393-402.

8. Akdemir N. Synthesis, characterization, and investigation of the spectroscopic properties of novel peripherally 2,3,5-trimethylphenoxy substituted $\mathrm{Cu}$ and Co phthalocyanines, computational and experimental studies of 4(2,3,5-trimethylphenoxy)phthalonitrile. Journal of the Turkish Chemical Society, Section A: Chemistry. 2016;3:683-706.

9. Irikura KK, Johnson RD, Kacker RN. Uncertainties in scaling factors for ab initio vibrational frequencies. J. Phys. Chem. A. 2005;109:8430-37.

10. Dennington R, Keith T, Millam J. GaussView, Version 5. 2009, Semichem Inc.: Shawnee Mission, KS.

11. Hanwell MD, Curtis DE, Lonie DC, Vandermeersch T, Zurek E, Hutchison GRJ. Avogadro: an advanced semantic chemical editor, visualization, and analysis platform. Cheminformatics. 2012;4:1-17. 
12. Lu T, Chen F. Multiwfn: A multifunctional wavefunction analyzer. J. Comput. Chem. 2012;33:580-92.

13. O'Boyle NM, Tenderholt AL, Langner KM. cclib: A library for package-independent computational chemistry algorithms. J. Comp. Chem. 2008;29:839-45.

14. Cancès $E$, Mennucci $B$, Tomasi J. A new integral equation formalism for the polarizable continuum model: Theoretical background and applications to isotropic and anisotropic dielectrics. J. Chem. Phys. 1997;107:3032-41.

15. Cancès E, Mennucci B. New applications of integral equations methods for solvation continuum models: ionic solutions and liquid crystals. J. Math. Chem. 1998;23:309-26.

16. Mennucci B, Cancès E, Tomasi J. Evaluation of Solvent Effects in Isotropic and Anisotropic Dielectrics and in Ionic Solutions with a Unified Integral Equation Method: Theoretical Bases, Computational Implementation, and Numerical Applications. J. Phys. Chem. B. 1997;101:10506-17.

17. Anacona J, Silva GD. Synthesis and antibacterial activity of cefotaxime metal complexes. J. Chil. Chem. Soc. 2005;50:447-50.

18. Fuliaş A, Bobric A, Vlase G, Vlase T, Doca N. Thermal stability and biological interactions. of some cephalosporins. Rev. Roum. Chim. 2011;56:959-66.

19. Barnes DJ, Chapman RL, Stephens FS, Vagg RS. Studies on the metal-amide bond. VII. Metal complexes of the flexible N4 ligand N, N'-bis(2'- pyridinecarboxamide)1,2-ethane. Inorg. Chim. Acta. 1981;51:155-62.

20. Garg BS, Bhojak N, Dwivedi P, Kumar V. Copper(II) complexes of acid amide derivatives of 2-aminopyridineand an exogenous ligand. Transit. Metal. Chem. 1999;24: 463-6.

21. Anacona JR, Bravo A, Lopez ME, Antibacterial Activity of Cefoperazone Metal Complexes. Lat. Am. J. Pharm. 2012;31:27-31.

22. Franchini GC, Giusti A, Preti C, Tosi L, Zannini P. Coordinating ability of methylpiperidine dithiocarbamates towards platinum group metals. Polyhedron, 1985, 9, 1553-1558.

23. Castillo M, Criado JJ, Macias B, Vaquero MV. Chemistry of dithiocarbamate derivatives of amino acids. I. Study of some dithiocarbamate derivatives of linear $\alpha$-amino acids and their nickel(II) complexes. Inorg. Chim. Acta. 1986;124:127-32.

24. El-Aziz AOA, El-Dars FM, Radowan AA. Novel allsolid contact Copper (II) - selective sensor based on Cefoperazone and poly(3,4ethylenedioxythiophene) (PEDOT) as conducting polymer. Journal of Inventions in Biomedical and Pharmaceutical Sciences (JIBPS). 2016;1:24-31.

25. Shungu, DL, Tutlane V, Gadebusch $\mathrm{HH}$. Multicenter evaluation of the proposed quality control limits and interpretive zone standards for in vitro susceptibility testing with norfloxacin. J. Clin. Microbiol. 1983;18:988-91.

26. Shungu DL, Weinberg E, Gadebusch, $H H$. Tentative interpretive standards for disk diffusion susceptibility testing with norfloxacin (MK-0366, AM-715). Antimicrob. Agents Chemother. 1983;23:256-60. 


\section{Supplementary Information}

\section{Investigation of cefoperazone metal complexes: an experimental and computational study}

Mehmet Emin Çınar ${ }^{1}$, Taner Erdoğan ${ }^{2}$ and Ayşegül Gölcü ${ }^{1, *}$

${ }^{1}$ Department of Chemistry, Faculty of Science and Letters, Istanbul Technical University, Istanbul, Turkey ${ }^{2}$ Kocaeli Univ, Kocaeli Vocat Sch, Dept Chem \& Chem Proc Technol, Kocaeli, Turkey.

*Correspondence: aysgolcu@itu.edu.tr

IR spectra of cefoperazone and its metal complexes

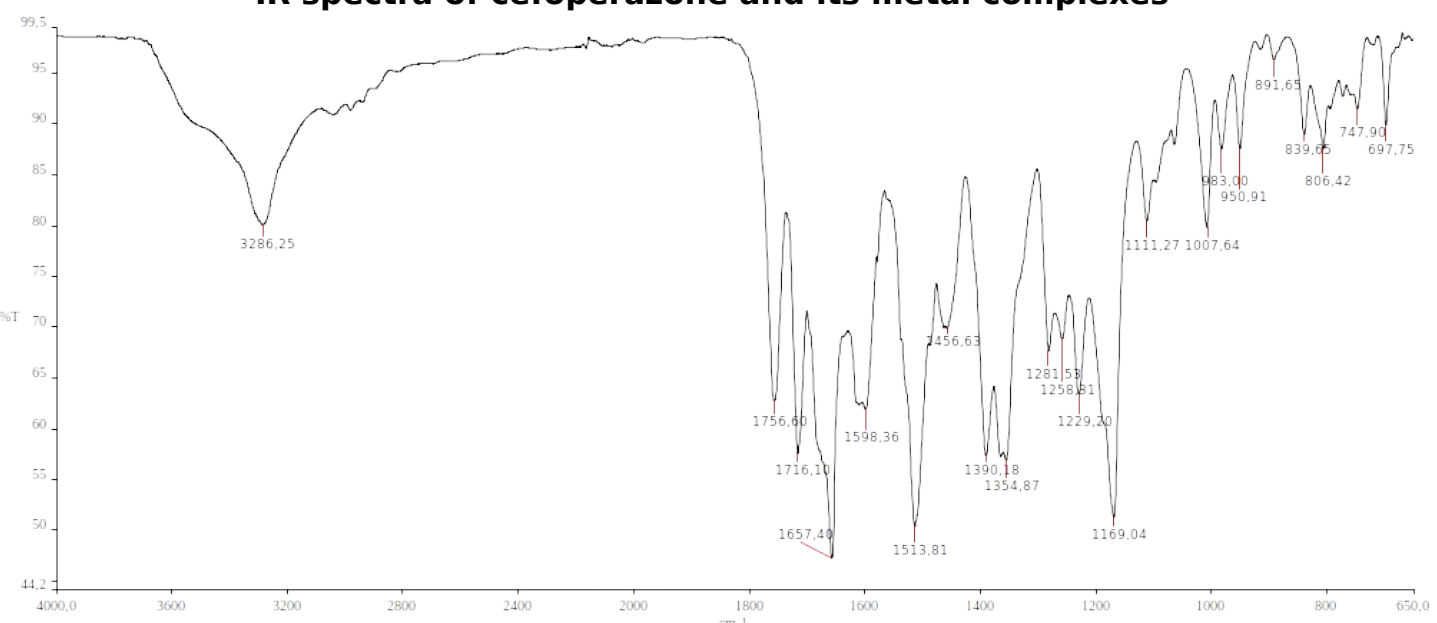

Figure S1. IR spectrum of cefoperazone.

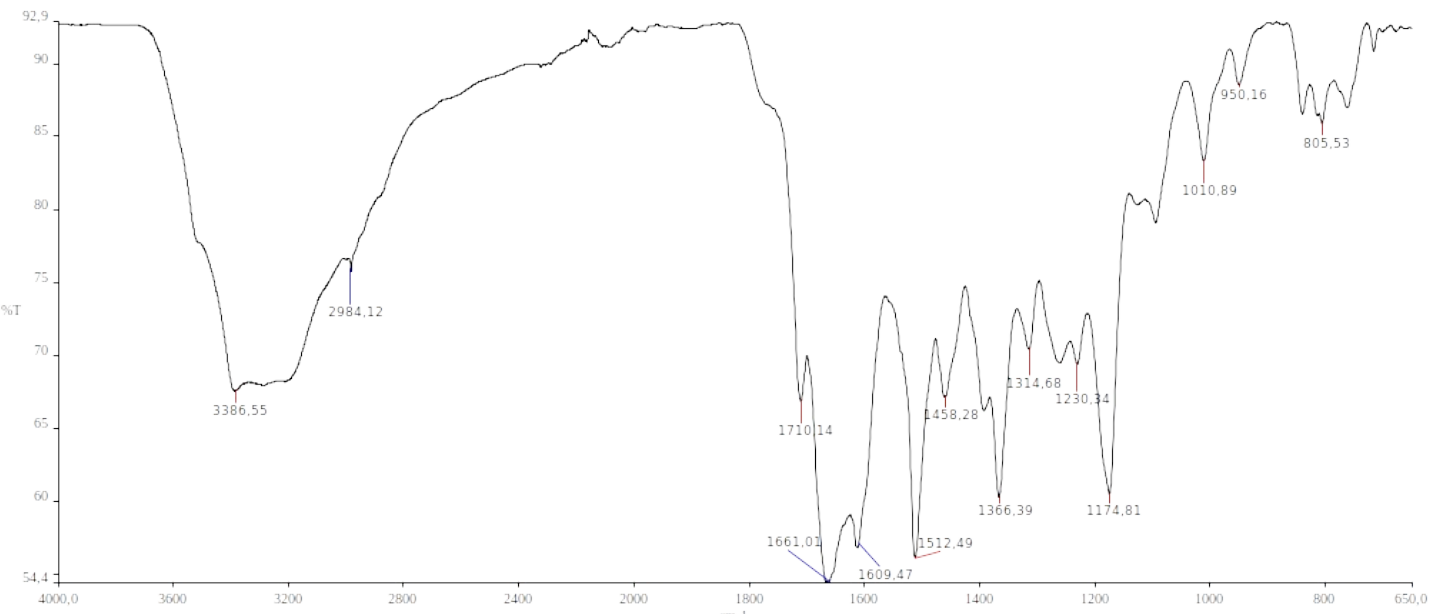

Figure S2. IR spectrum of $\mathrm{Cu}$ (II)-cefoperazone complex. 


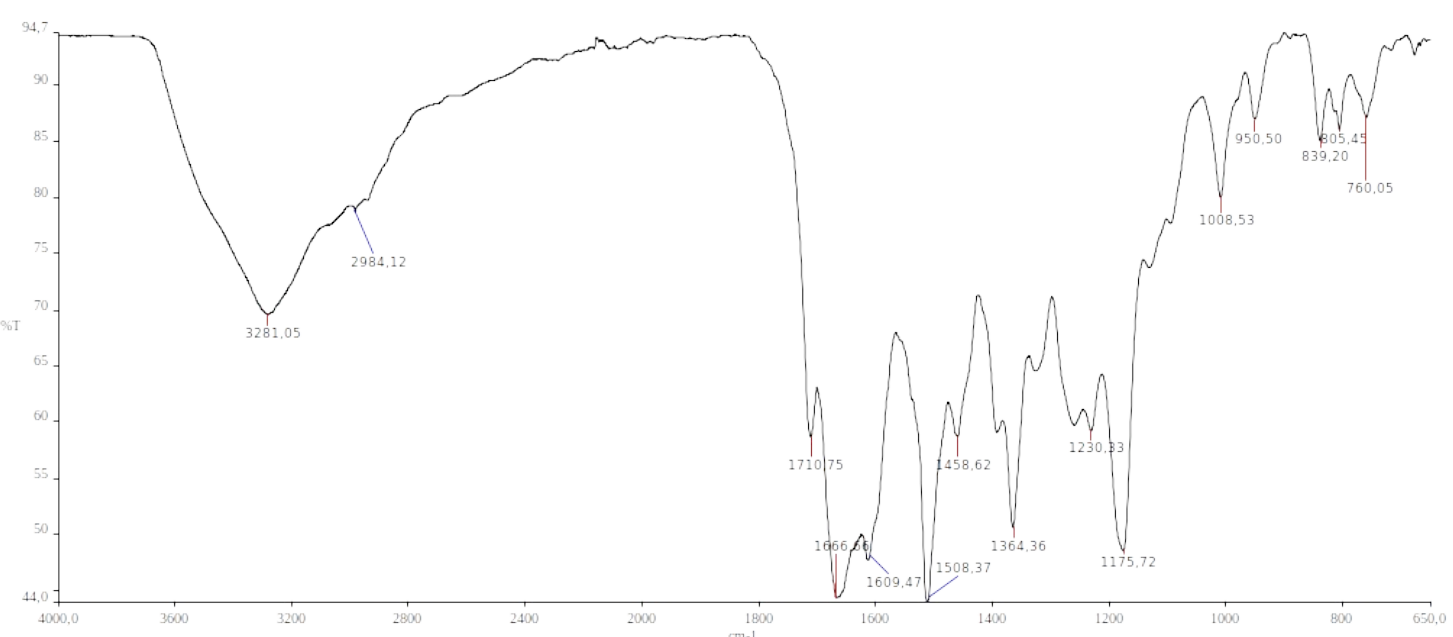

Figure S3. IR spectrum of Co(II)-cefoperazone complex.

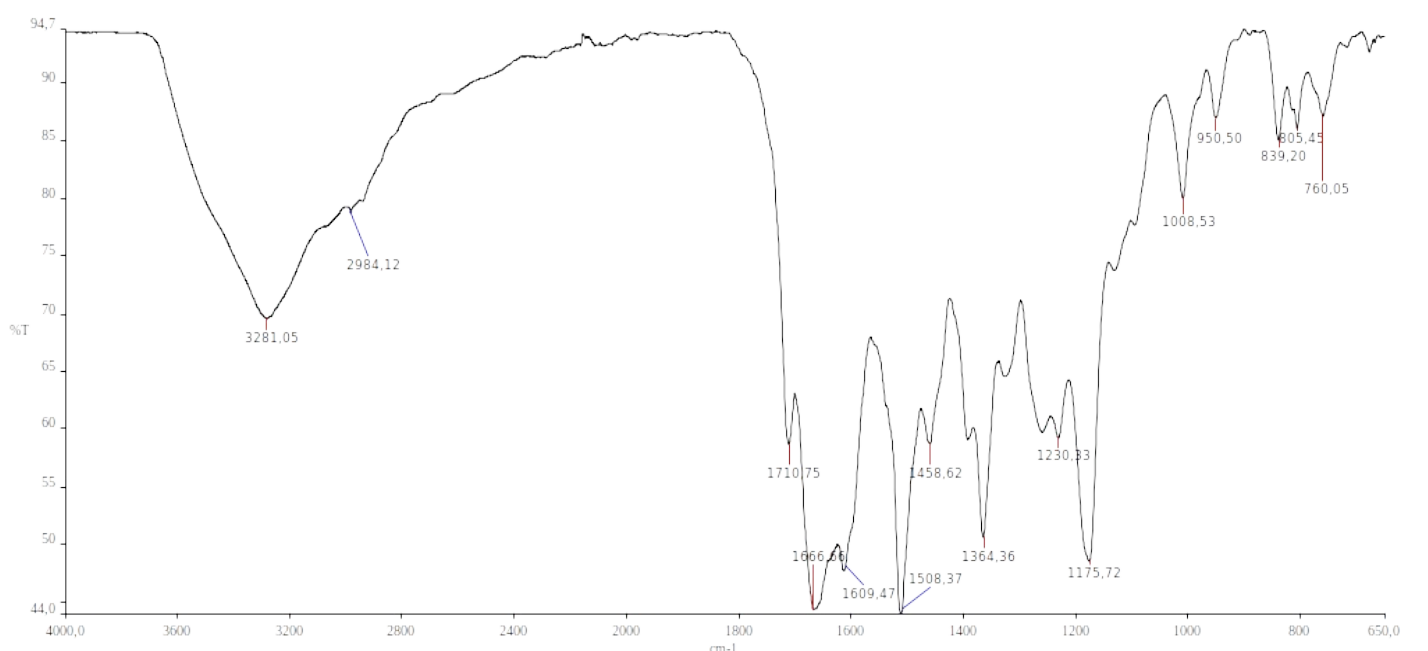

Figure S4. IR spectrum of $\mathbf{N i ( I I ) - c e f o p e r a z o n e ~ c o m p l e x . ~}$

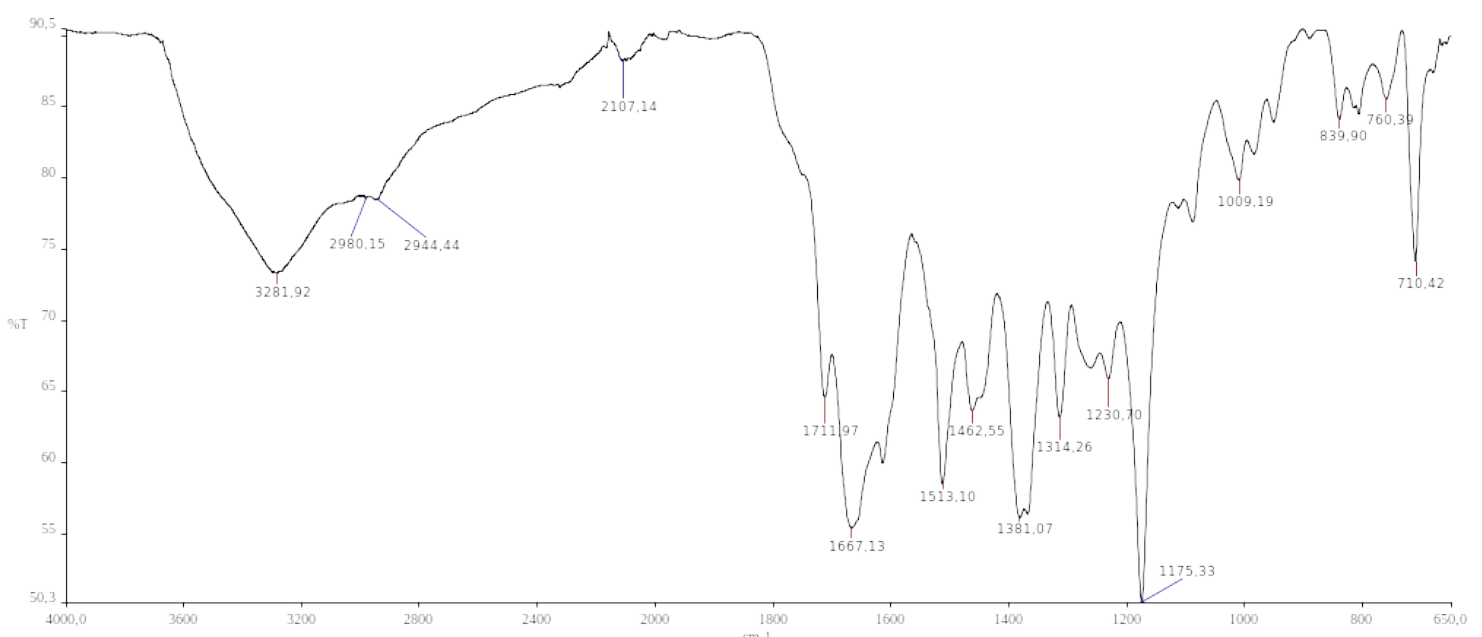

Figure S5. IR spectrum of Zn(II)-cefoperazone complex. 


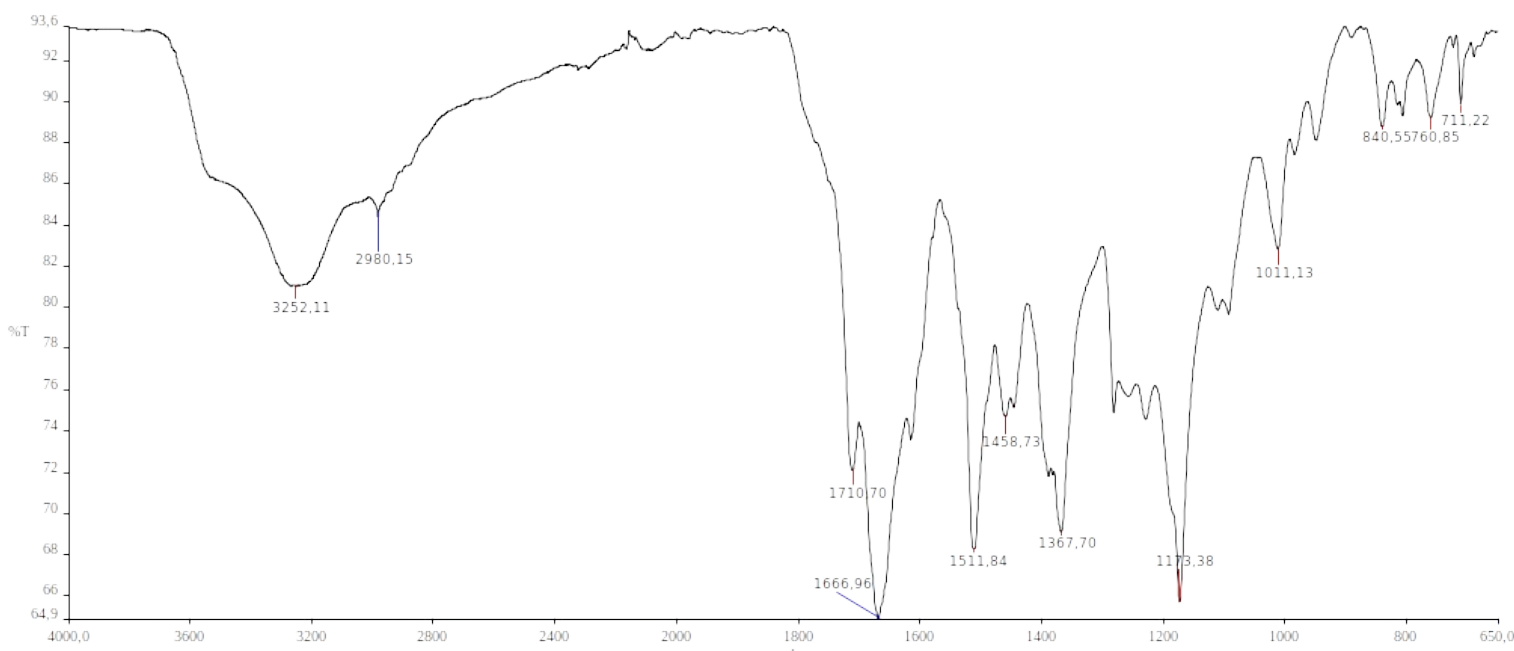

Figure S6. IR spectrum of Cd(II)-cefoperazone complex.

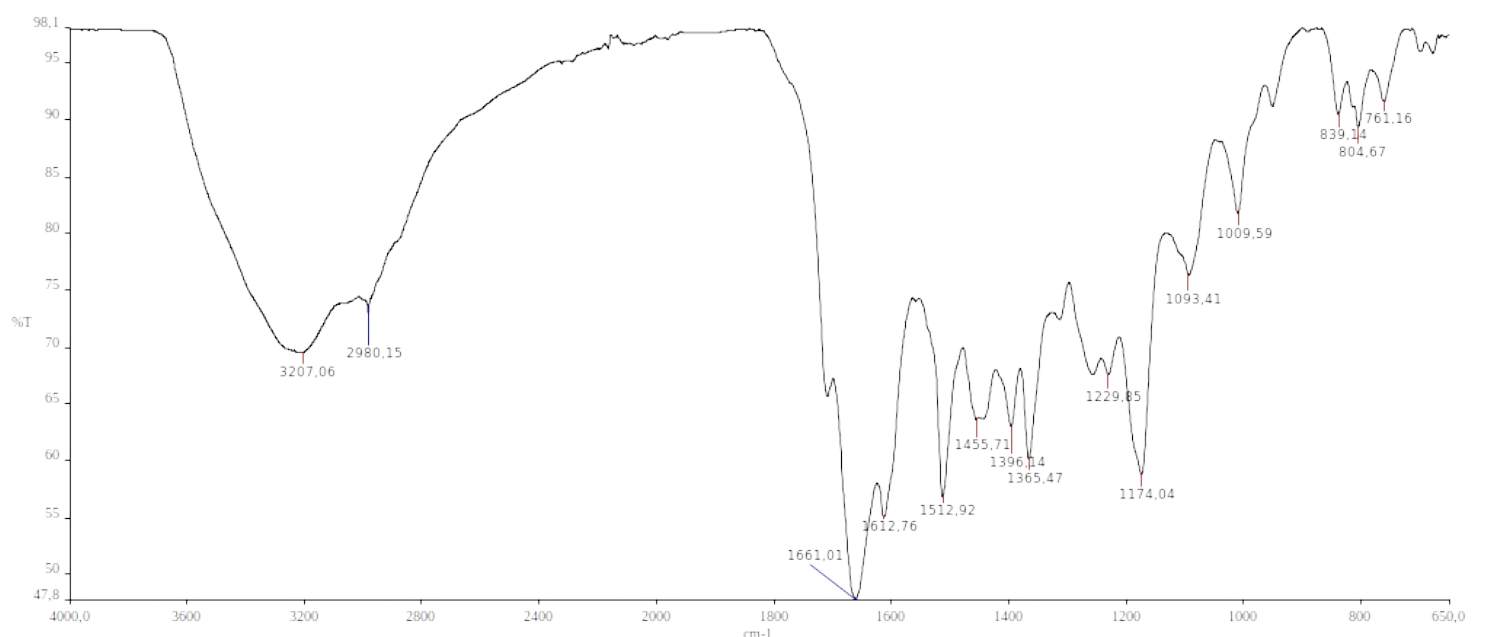

Figure S7. IR spectrum of Fe(III)-cefoperazone complex.

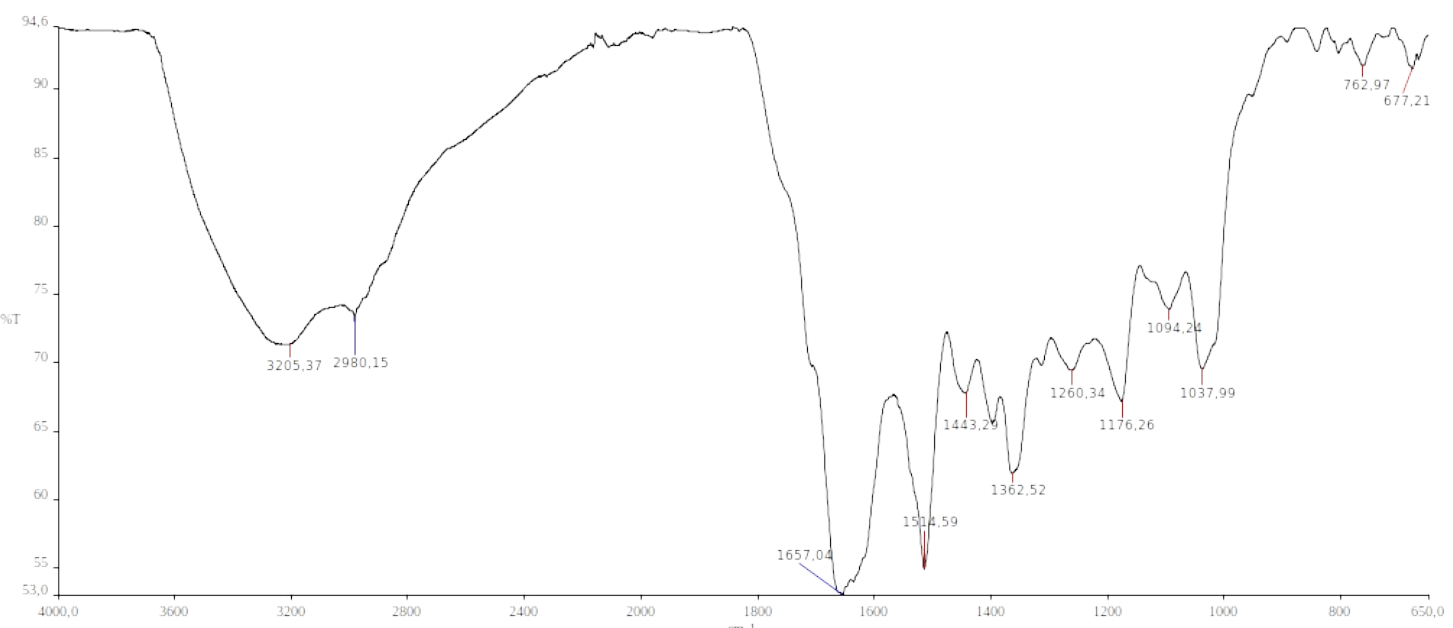

Figure S8. IR spectrum of Ru(III)-cefoperazone complex. 


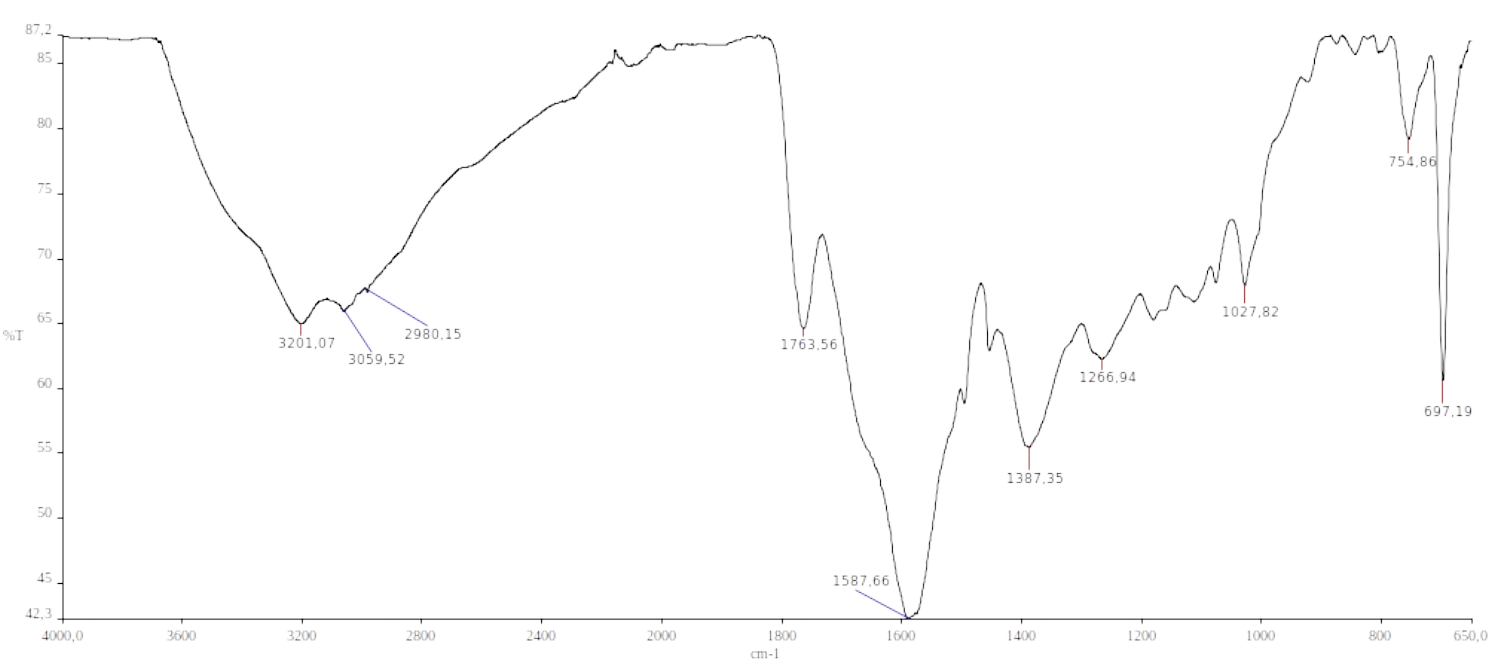

Figure S9. IR spectrum of $\mathrm{Pd}(\mathrm{II})$-cefoperazone complex. 
